\title{
ANALISIS INTENSI MENABUNG PADA BANK SYARIAH DENGAN IMPORTANCE-PERFORMANCE MATRIX ANALYSIS (IPMA)
}

\author{
Sulistyandari ${ }^{1}$ \& M. Arna Ramadhan ${ }^{2}$ \\ ${ }^{1}$ Universitas Muhammadiyah Riau \\ ${ }^{2}$ Buka Data Indonesia \\ Email:sulistyandari@umri.ac.id, arnaramadhan@ymail.com
}

\begin{abstract}
ABSTRAK
Pertumbuhan aset perbankan syariah di Indonesia terus mengalami peningkatan yang signifikan. Hal tersebut menunjukkan bahwa masyarakat mempunyai intensi yang baik untuk menabung di Bank Syariah. Penelitian ini mengidentifikasi faktor-faktor yang berperan dalam mempengaruhi intensi menabung di Bank Syariah, di antaranya religiusitas, kualitas layanan, dan kepercayaan. Penelitian melalui survei terhadap 250 responden dan dianalisis dengan menggunakan importance-performance matrix analysis (IPMA). Hasil penelitian menyajikan tingkat kepentingan (importance) dan performa (performance) untuk setiap variabel dan indikator-indikatornya. Kualitas layanan menjadi variabel yang paling berperan dalam mempengaruhi intensi menabung di Bank Syariah, namun mempunyai performa yang masih rendah. Aspek-aspek kualitas layanan yang perlu untuk diperhatikan agar dapat meningkatkan intensi menabung masyarakat, yaitu penerapan hukum dan prinsip Islam pada Bank Syariah secara utuh, meniadakan bunga bank (riba), adanya kerjasama dan dukungan dari pihak lain dengan Bank Syariah, biaya layanan yang lebih rendah, aset dan modal Bank Syariah yang semakin besar, dan kemudahan dalam pengajuan pinjaman/pembiayaan dengan persyaratan yang tidak memberatkan nasabah.
\end{abstract}

Kata Kunci : Intensi, IPMA, Bank Syariah, Kualitas Layanan, Religiusitas.

\begin{abstract}
Islamic Banking assets growth in Indonesia increase significantly. This shows that people have good intentions to save their money in Islamic Banks. This study identifies factors that affect the intention of money saving in Islamic Banks, including religiosity, service quality, ant trust. The study was conducted through a survey of 250 respondents and analyzed using importance-performance matrix analysis (IPMA). The result of study showed the importance and the performance of each variable and its indicators. Service quality is the most affected variable to intention of money saving in Islamic Banks, but has low performance. The aspects of service quality that need to be improved in order to increase the money saving intention, namely the application of Islamic law and principles in Islamic Banking as a whole, eliminating bank interest (riba), the existence of cooperation and support from other parties, lower services fees, larger assets and capital, and ease in applying for financing with modest terms and conditions.
\end{abstract}

Keywords : Intention, IPMA, Islamic Banking, Service Quality, Religiosity. 


\section{PENDAHULUAN}

Perbedaan pokok antara perbankan syariah dan konvesional yaitu sistem bunga (Sayani \& Miniaoui, 2013). Perbankan Syariah di Indonesia terus mengalami pertumbuhan yang positif. Otoritas Jasa Keuangan (2020) mencatat bahwa aset perbankan syariah di akhir tahun 2020 mencapai 593,948 miliar rupiah atau meningkat sebesar 237,444 miliar rupiah dibanding tahun 2016 yang hanya mencapai 356.504 miliar rupiah. Perkembangan aset perbankan syariah tersebut menjadi indikator bahwa masyarakat Indonesia mempunyai intensi menabung yang tinggi di Bank Syariah.

Ada banyak faktor yang mempengaruhi intensi masyarakat untuk menabung di Bank Syariah. Salah satu faktor tersebut adalah religiusitas. Seseorang yang memiliki tingkat religiusitas yang tinggi akan cenderung tertarik untuk menabung di Bank Syariah (Kardoyo et al., 2020). Penelitian yang dilakukan oleh Afiah (2016) menemukan bahwa religiusitas mempunyai pengaruh positif yang signifikan terhadap intensi menabung di Bank Syariah.

Kepercayaan masyarakat terhadap Bank Syariah juga mempunyai peran bagi intensi menabung. Penelitian Suhartanto et al., (2018) membuktikan bahwa kepercayaan seseorang akan memengaruhi intensi menabung dan loyalitas terhadap Bank Syariah.

Hal penting lainnya yang mempunyai kontribusi terhadap intensi menabung adalah kualitas layanan atau service quality. Layanan yang baik dari Bank Syariah akan memberikan kenyamanan bagi nasabah untuk terus melakukan transaksi keuangan, termasuk menabung. Choudhury (2015) menunjukkan bahwa kualitas layanan sangat mempengaruhi intensi menabung di Bank Syariah.
Penelitian ini bertujuan untuk mengidentifikasi faktor-faktor yang mempunyai kontribusi penting bagi intensi masyarakat Indonesia untuk menabung di Bank Syariah. Di samping itu, penelitian ini juga akan memetakan dan mengevaluasi aspek-aspek yang perlu diperhatikan berdasarkan persepsi masyarakat, khususnya para nasabah perbankan syariah untuk meningkatkan intensi menabung di Bank Syariah.

\section{TINJAUAN PUSTAKA}

$\begin{array}{ccr}\text { Intensi } & \begin{array}{c}\text { merupakan } \\ \text { konsumen }\end{array} & \text { sebuah } \\ \text { keinginan } & \text { untuk }\end{array}$ menggunakan suatu produk atau jasa berdasarkan persepsi dari kepuasan suatu layanan (Amini, Muflih, \& Marwansyah, 2020). Intensi menabung di Bank Syariah dirumuskan atas 5 indikator, yaitu intensi untuk terus menggunakan layanan tabungan Bank Syariah, intensi untuk menggunakan layanan tabungan Bank Syariah meski biaya meningkat, intensi untuk merekomendasikan layanan tabungan Bank Syariah kepada orang lain, intensi untuk tetap menjadi nasabah Bank Syariah di masa mendatang, dan turut menyebarkan informasi positif tentang layanan tabungan Bank Syariah (Kaabachi \& Obeid, 2016).

Religiusitas adalah keyakinan dan ibadah seseorang terhadap ketuhanan (Souiden \& Rani, 2015). Religiusitas mempunyai pengaruh yang signifikan terhadap intensi menabung seseorang di Bank Syariah (Amini, Muflih \& Marwansyah, 2020; Muslichah \& Sanusi, 2019).

Kualitas layanan (service quality) didefinisikan sebagai perbedaan antara harapan (expectation) dan kinerja (performance) dari suatu layanan (Parasuraman et al., 1985). Kualitas layanan mempunyai pengaruh yang paling besar terhadap loyalitas seseorang di dalam industri perbankan 
(Boonlertvanich, 2019). Tingginya tingkat loyalitas seseorang maka akan semakin meningkatkan intensi menabung di Bank Syariah, bahkan kualitas layanan yang baik telah terbukti secara signifikan terhadap intensi dan loyalitas orangorang Indonesia untuk menabung di Bank Syariah (Fusva et al., 2020).

Kepercayaan dapat didefinisikan sebagai sebuah keyakinan seseorang terhadap pihak lain yang dapat memenuhi kebutuhan atau keinginan di masa yang akan datang (Carlos, Miguel, \& Eduardo, 2005). Muslim, Zaidi, \& Rodrigue (2013) mendefinisikan kepercayaan sebagai "a moral obligation of every individual in the performance of his or her duties in society". Kepercayaan mempunyai pengaruh yang signifikan terhadap intensi dan kesetiaan menabung di Bank Syariah (Suhartanto et al., 2018).

\section{METODE PENELITIAN}

Penelitian ini berupa studi kuantitatif dimana pengumpulan data dilakukan melalui survei dengan menggunakan kuesioner. Sampel penelitian ini adalah nasabah Bank Syariah dan Unit Usaha Syariah di Provinsi Riau, di antaranya Bank Syariah Mandiri, Bank Muamalat Indonesia, Bank Mega Syariah, Bank BRI Syariah, Bank BNI Syariah, Bank Riau \& Kepri Syariah, Bank BTN Syariah, dan Bank Permata Syariah. Pengambilan sampel dilakukan dengan teknik non-probability sampling dengan jumlah sampel sebanyak 250 orang nasabah.

$$
\text { Variabel dependen dalam }
$$
penelitian ini adalah intensi menabung di Bank Syariah sedangkan variabelvariabel independen yang digunakan adalah religiusitas, kualitas layanan, dan kepercayaan. Variabel-variabel tersebut diukur dengan menggunakan indikatorindikator kuesioner berskala Likert dengan skor 1-5 dimana 1 diberikan untuk jawaban "sangat tidak setuju" dan 5 untuk jawaban "sangat setuju".

Tabel 1. Variabel dan Indikator Penelitian

\begin{tabular}{|c|c|c|c|}
\hline Variabel & Dimensi & $\begin{array}{c}\text { Jumlah } \\
\text { Indikator }\end{array}$ & Sumber \\
\hline Intensi & Pribadi, Sosial, dan Informasi & 8 & Fishbein \& Ajzen (2010) \\
\hline Religusitas & $\begin{array}{l}\text { Akidah, Ibadah, } \\
\text { Pengetahuan }\end{array}$ & 9 & Nashori \& Mucharam (2002) \\
\hline Kualitas Layanan & $\begin{array}{l}\text { Kepatuhan, Jaminan, } \\
\text { Keandalan, Bukti } \text { Fisik, } \\
\text { Perhatian, dan Daya Tanggap }\end{array}$ & 23 & $\begin{array}{l}\text { Zeithaml, Bitner, \& Gremler } \\
\text { (2017); Othman \& Owen (2011) }\end{array}$ \\
\hline Kepercayaan & $\begin{array}{l}\text { Kredibilitas, Kebajikan, dan } \\
\text { Integritas }\end{array}$ & 6 & Mansour et al. (2016) \\
\hline
\end{tabular}

Sumber: Data Peneliti (2021)

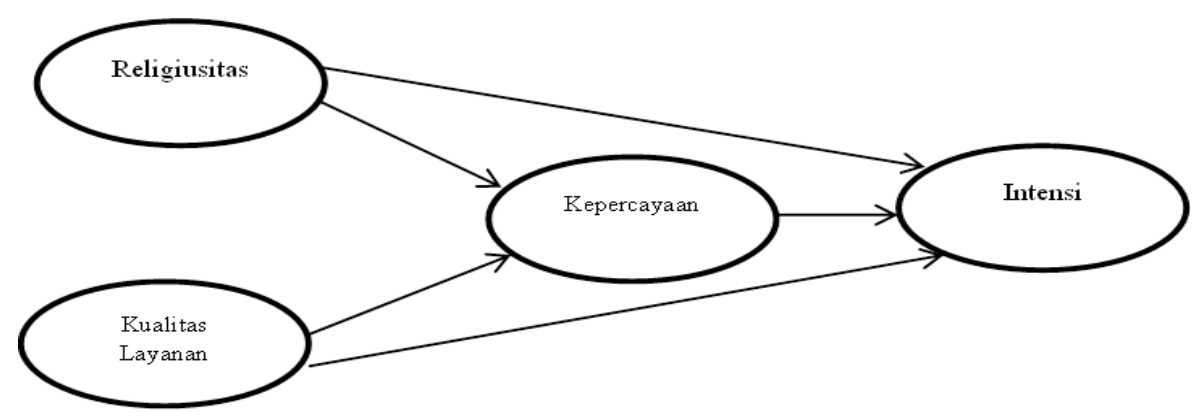

Gambar 1. Kerangka Penelitian 
IPMA adalah akronim dari dependen dan performa (performance) Importance Performance Matrix yang menunjukkan nilai rata-rata variabel Analysis, sebuah teknik analisis yang tersebut (Tailab, 2020; Jaafar et al., dikembangkan pertama kali oleh Martilla 2016). Tujuan dari IPMA adalah \& James (1977). IPMA terdiri atas 2 mengidentifikasi tingkat kepentingan dari dimensi, yaitu tingkat kepentingan masing-masing variabel independen dan (importance) suatu variabel yang performanya terhadap variabel dependen menunjukkan pengaruh total (total effect) (Abalo et al., 2007; Minta \& Stephen, variabel tersebut terhadap variabel 2017).

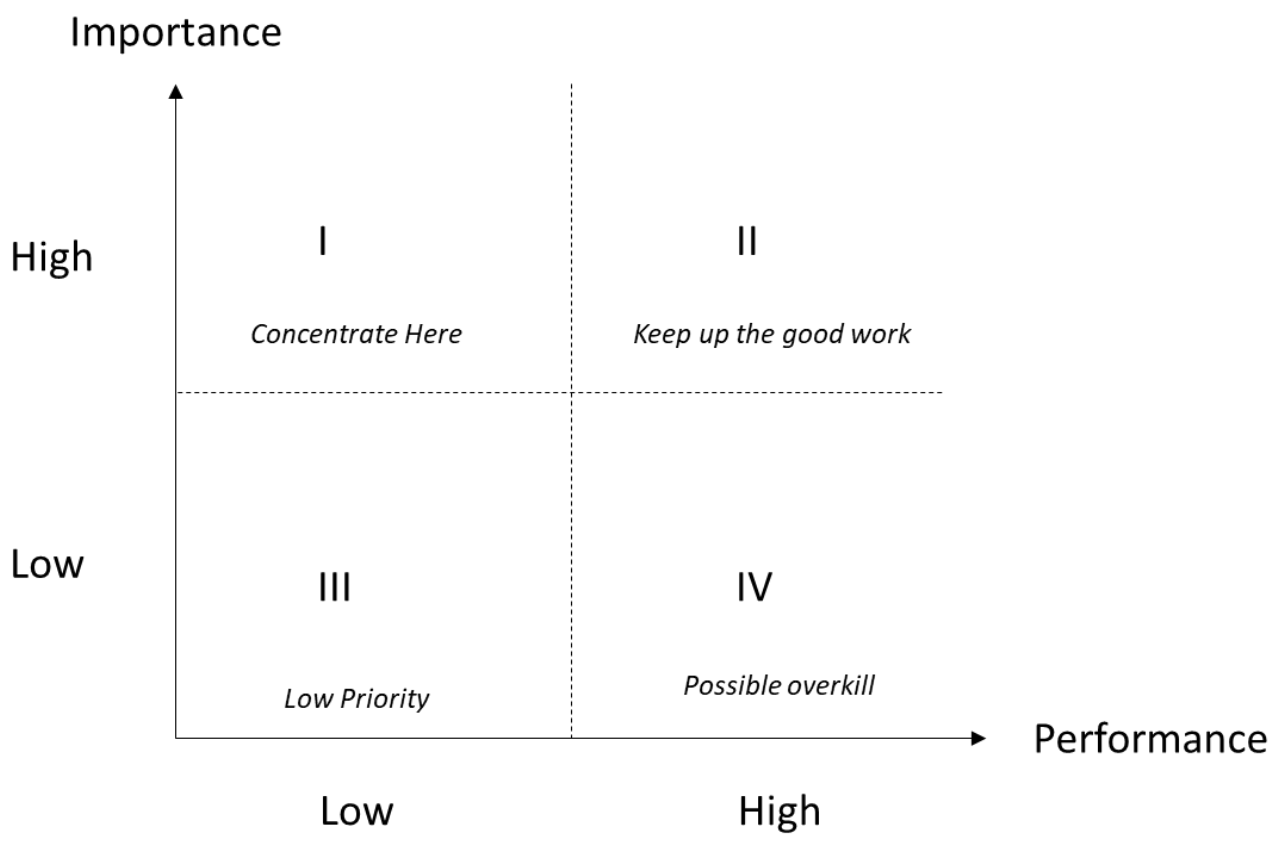

\section{Gambar 2. Importance Performance Matrix Analysis (IPMA)}

IPMA terbagi ke dalam 4 kuadran sebagaimana yang ditunjukkan oleh Gambar 2. Kuadran I didefinisikan sebagai "concentrate here" yang menunjukkan suatu variabel mempunyai tingkat kepentingan yang tinggi namun performa yang rendah sehingga variabel yang masuk ke dalam kuadran ini harus menjadi perhatian khusus dan diberikan improvisasi atau perbaikan. Kuadran II didefinisikan "keep up the good work" yang menunjukkan variabel yang mempunyai tingkat kepentingan tinggi. dan performa yang tinggi. Kuadran III sebagai "low priority" yaitu bagian untuk variabel dengan tingkat kepentingan rendah dan performa yang rendah juga. Adapun kuadran IV yaitu "possible overkill" yang menunjukkan variabel dengan tingkat kepentingan yang rendah akan tetapi mempunyai performa yang tinggi sehingga variabel pada kuadran IV bisa diabaikan (Minta \& Stephen, 2017; Shieh \& Wu, 2009).

\section{HASIL DAN PEMBAHASAN}

\section{Uji Normalitas}

Uji normalitas berguna untuk menguji apakah dalam model regresi variabel independen dan variabel dependen berdistribusi normal atau mendekati normal.

Analisis data dilakukan terhadap data kuesioner yang dikumpulkan dari 250 orang nasabah Bank Syariah di Provinsi Riau. IPMA memberikan hasil pada level 
variabel dan indikator penelitian. Variabel IPMA pada level variabel. Tingkat religiusitas terdiri atas 9 indikator (X1 - kepentingan paling besar atau pengaruh X19), variabel kualitas layanan terdiri atas terbesar terhadap intensi menabung 23 indikator (X21 - X223), dan variabel nasabah adalah variabel kualitas layanan kepercayaan terdiri atas 6 indikator (Z1 - dengan tingkat kepentingan sebesar 0.54 Z6). Tabel 2 menunjukkan nilai dari dengan performa sebesar 82.60 sedangkan tingkat kepentingan (importance) dan variabel dengan tingkat kepentingan paling performa (performance) berdasarkan rendah adalah religiusitas.

Tabel 2. IPMA Intensi Menabung

\begin{tabular}{lcc}
\hline \multicolumn{1}{c}{ Variabel } & $\begin{array}{c}\text { Performance } \\
\text { (Score) }\end{array}$ & $\begin{array}{c}\text { Importance } \\
\text { (Total Effect) }\end{array}$ \\
\hline Religiusitas & 82.20 & 0.22 \\
Kualitas Layanan & 82.60 & 0.54 \\
Kepercayaan & 85.20 & 0.35 \\
\hline
\end{tabular}

Gambar 3 merupakan diagram IPMA level variabel intensi menabung. Kualitas layanan terklasifikasikan ke dalam kuadran I, artinya kualitas layanan mempunyai tingkat kepentingan yang tinggi terhadap intensi menabung, akan tetapi performa yang dicapai saat ini masih dalam kategori rendah sehingga perlu improvisasi, perbaikan, dan peningkatan kualitas layanan yang diberikan oleh Bank Syariah kepada nasabah. Religiusitas diklasifikasian ke dalam kuadran III yang mempunyai tingkat kepentingan yang rendah dan juga performa yang rendah, artinya religiusitas tidak menjadi faktor yang sangat penting bagi nasabah untuk menabung di Bank Syariah. Kepercayaan masuk ke dalam kuadran IV yang menunjukkan bahwa kepercayaan mempunyai tingkat kepentingan yang rendah namum performa yang baik. Hal ini menunjukkan bahwa meski kepercayaan tidak menjadi aspek terbesar yang mendorong nasabah untuk menabung di Bank Syariah, tetapi kepercayaan nasabah terhadap Bank Syariah sangat tinggi dalam menjalankan kewajibannya, baik dalam dimensi kredibilitas, kebajikan, maupun integritas.

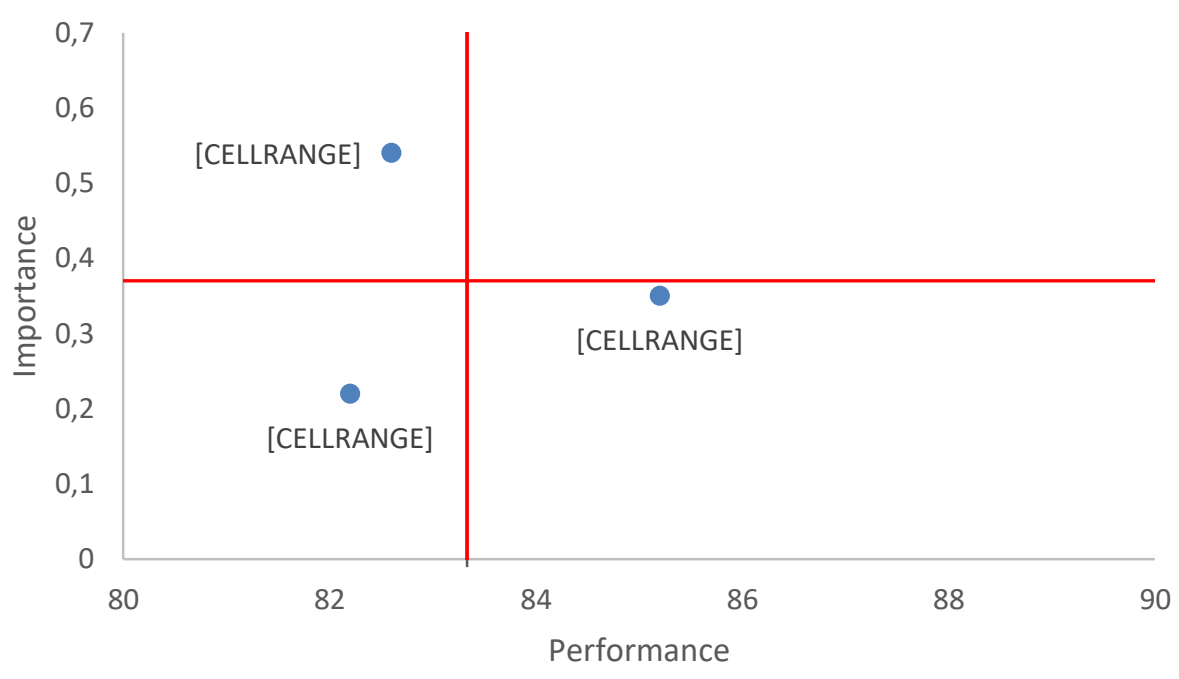

Gambar 3. Diagram IPMA Intensi Menabung 
Selain menampilkan tingkat kepentingan dan performa pada level variabel, IPMA juga mengevaluasi tingkat kepentingan dan performa dari setiap indikator yang ada pada variabel-variabel penelitian. Diagram IPMA untuk indikator-indikator pada variabel religiusitas ditampilkan pada Gambar 4.

Dua indikator yang mempunyai tingkat kepentingan yang tinggi dan performa yang baik berada dalam kuadaran II adalah X11 (ketakwaan/keyakinan) dan X15 (menabung untuk memaslahatan). Indikator-indikator yang harus diperhatikan untuk dilakukan oerbaikan dan peningkatan dalam aspek religiusitas berada dalam kuadran I, yaitu X12 (keyakinan terkait keselamatan dunia dan akhirat), X13 (persepsi bahwa menabung adalah bagian dari ibadah), dan X19 (aspek pengetahuan terkait kesediaan mengatur waktu untuk membaca dan mengkaji ilmu agama Islam).

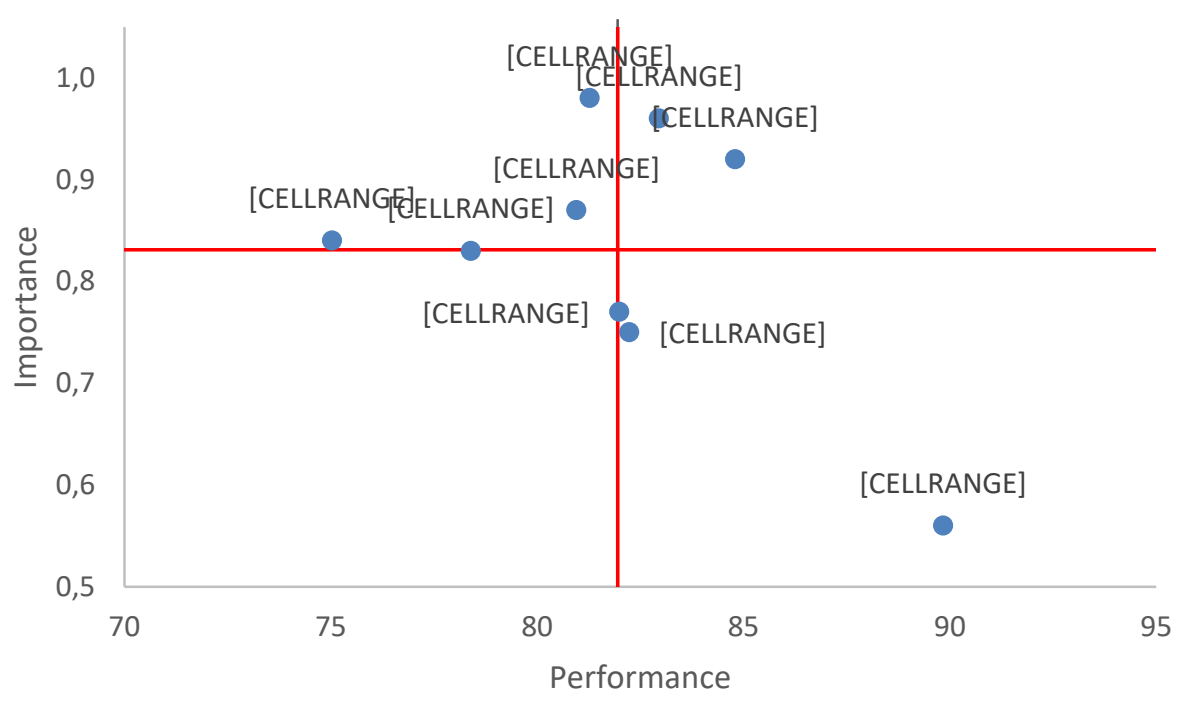

\section{Gambar 4. Diagram IPMA Indikator Religiusitas}

Kualitas layanan menjadi variabel dengan tingkat kepentingan yang paling besar namun mempunyai performa yang rendah sehingga kualitas layanan harus menjadi perhatian khusus yang perlu ditingkatkan performanya. Gambar 5 menampilkan IPMA untuk indikatorindikator variabel kualitas layanan, dimana terdapat 6 indikator dari 23 indikator kualitas layanan yang diklasifikasikan ke dalam kuadran I sehingga perlu perbaikan dan peningkatan performa untuk keenam indikator tersebut.
Enam indikator kualitas layanan yang berada dalam kuadran I adalah X21 (dijalankan berdasarkan hukum dan prinsip Islam), X22 (tidak ada bunga bank), X212 (lingkungan luar yang ikut mendukung kegiatan Bank Syariah), X217 (biaya layanan yang lebih rendah), X219 (aset dan modal yang besar), dan X223 (Bank Syariah menyediakan fasilitas pinjaman/pembiayaan dengan persyaratan yang tidak memberatkan nasabah). 


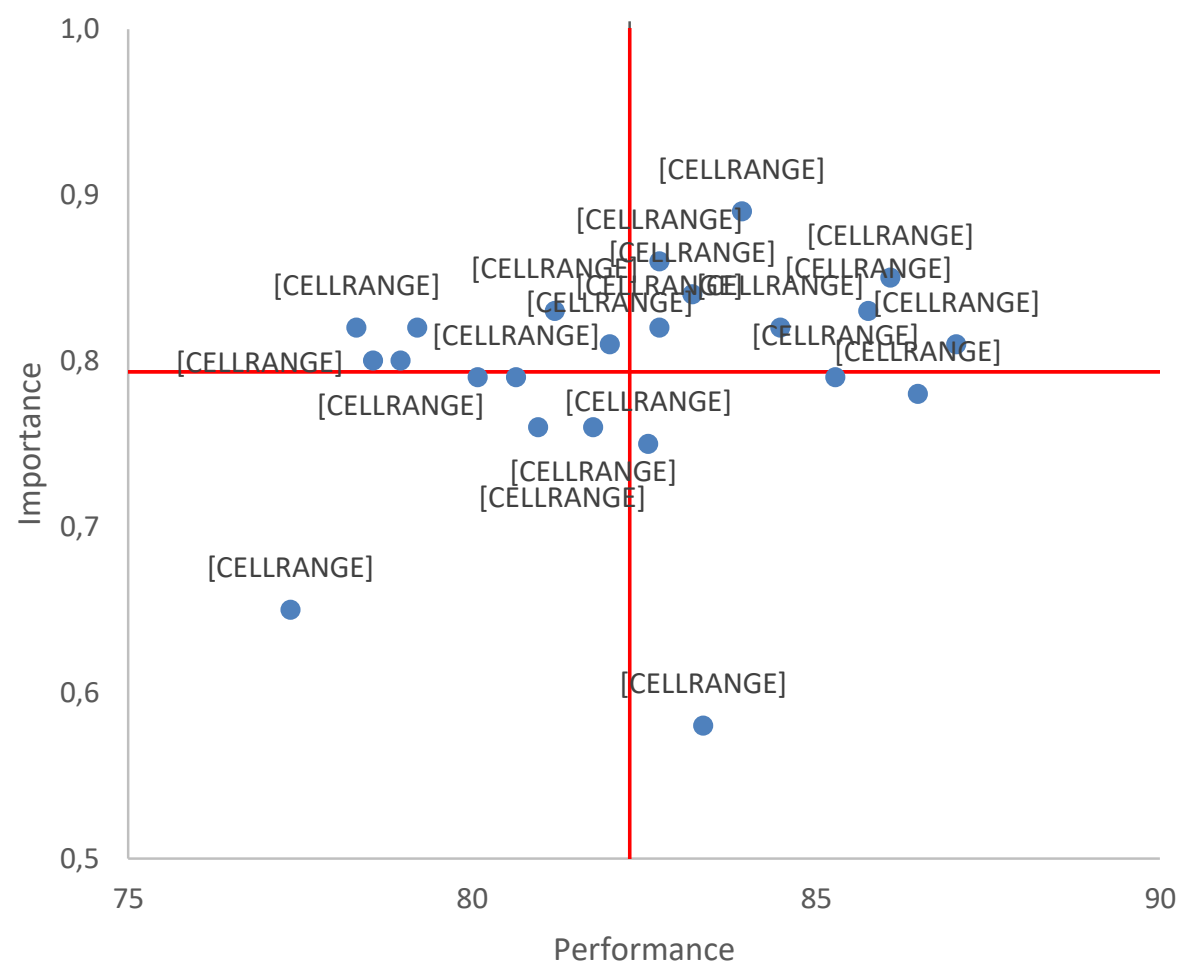

Gambar 5. Diagram IPMA Indikator Kualitas Layanan

Gambar 6 menampilkan IPMA ditingkatkan performanya adalah Z1 untuk indikator kepercayaan. Variabel (dijalankan berdasarkan prinsip-prinsip kepercayaan terdiri atas 6 indikator yaitu Islam), Z2 (produk dan layanan yang Z1 - Z6. Kepercayaan menjadi variabel sesuai dengan agama Islam), dan Z4 yang mempunyai tingkat kepentingan (konsisten dalam memberikan layanan tertinggi kedua setelah kualitas layanan yang baik). Ketiga indikator tersebut dengan tingkat kepentingan sebesar 0.35. diklasifikasikan ke dalam kuadran I yang Berdasarkan hasil IPMA, terdapat 2 mempunyai tingkat kepentingan yang indikator yang termasuk ke dalam kuadran tinggi namun performa yang dimiliki II atau mempunyai tingkat kepentingan masih rendah sehingga perlu dilakukan tinggi dan performa yang baik yaitu Z3 improvisasi pada indikator-indikator (keamanan tabungan) dan Z5 (terkait tersebut untuk dapat meningkatkan intensi integritas yaitu kejujuran). Indikator- nasabah menabung pada Bank Syariah. 


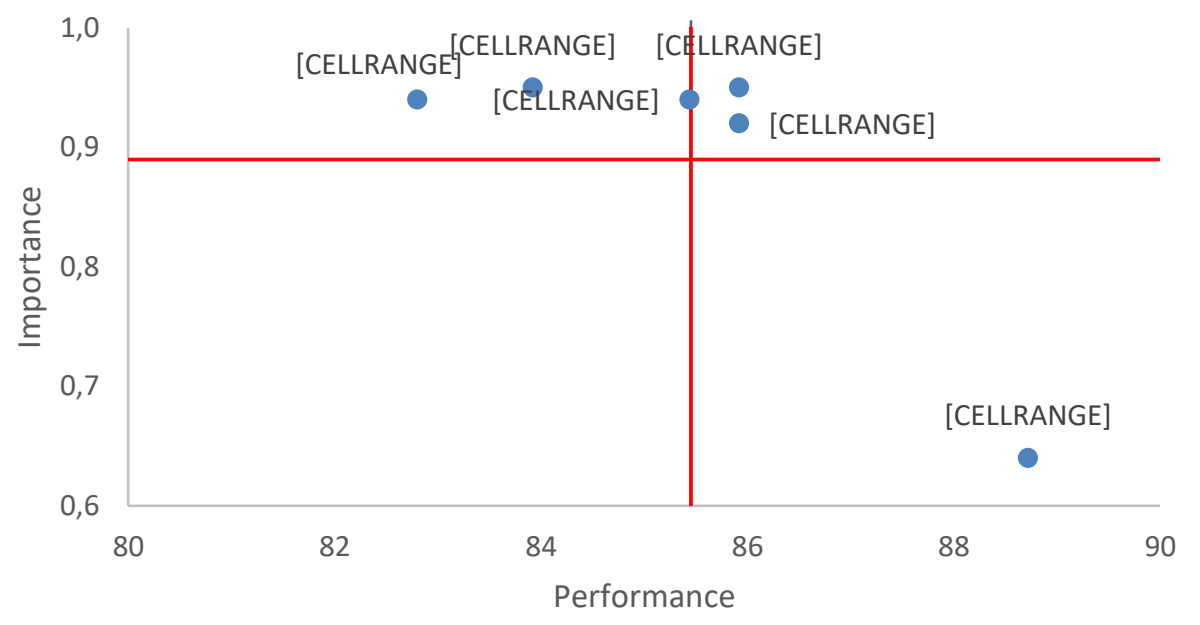

\section{Gambar 6. Diagram IPMA Indikator Kepercayaan}

\section{KESIMPULAN}

Intensi menabung masyarakat kepada Bank Syariah telah mengalami peningkatan, hal ini ditunjukkan oleh tren positif dari total aset perbankan Syariah. Intensi menabung masyarakat dipengaruhi beberapa faktor, di antaranya religiusitas, kualitas layanan, dan kepercayaan. Penelitian ini mengidentifikasi tingkat kepentingan (importance) atau kontribusi religiusitas, kualitas layanan, dan kepercayaan serta performanya (performance) terhadap intensi menabung. Hasil penelitian terhadap 250 orang nasabah Bank Syariah di Provinsi Riau dengan menggunakan metode IPMA (Imporatance-Performance Matrix Analysis) menunjukkan bahwa kualitas layanan menjadi satu-satunya faktor yang mempunyai tingkat kepentingan dan pengaruh terbesar bagi intensi menabung nasabah. Akan tetapi, tingkat kepentingan kualitas layanan yang besar tidak diiringi dengan performa yang baik sehingga kualitas layanan perlu diperbaiki dan ditingkatkan agar intensi menabung nasabah di perbankan syariah dapat dipertahankan dan ditingkatkan. Beberapa aspek penting dari kualitas layanan yang harus menjadi perhatian penting bagi Bank Syariah untuk dapat meningkatkan intensi menabung nasabah yaitu penerapan hukum dan prinsip Islam pada Bank Syariah secara utuh, meniadakan bunga bank (riba), adanya kerjasama dan dukungan dari pihak lain dengan Bank Syariah, biaya layanan yang lebih rendah, aset dan modal Bank Syariah yang semakin besar, dan kemudahan dalam pengajuan pinjaman/pembiayaan dengan persyaratan yang tidak memberatkan nasabah.

\section{DAFTAR PUSTAKA}

Abalo, J., Varela, J., \& Manzano, V. 2007. Importance Values for ImportancePerformance Analysis: A Formula for Spreading Out Values Derived from Preference Rankings. Journal of Business Research, 60(5), p. 115-121.

Afiah, Y. 2016. Pengaruh Religiusitas dan Persepsi Masyarakat Desa Bode Lor terhadap Minat Menabung di Perbankan Syariah. Skripsi Jurusan Muamalah Hukum Ekonomi Syariah. IAIN Syekh Nurjati Cirebon.

Amini, N.H., Muflih, M., \& Marwansyah. 2020. The Effect of Religiosity and Financial Considerations on Behavioral Intention toward Islamic Banking Industry: The Mediating Role of Attitude. Advances in Engineering Research, 198, p. 552559. 
Boonlertvanich, K. 2019. Service quality, Satisfaction, Trust, and Loyalty: The Moderating Role of Main-Bank And Wealth Status. International Journal of Bank Marketing, 37(1), p. 278302.

Carlos, F., Miguel, G., \& Eduardo, T. 2005. The Influence of Corporate Image on Consumer Trust: A Comparative Analysis In Traditional Versus Internet Banking. Internet Research, 15(4), p. 447-470.

Choudhury, K. 2015. Service Quality and Customers' Behavioural Intentions: Class and Mass Banking and Implications for The Consumer and Society. Asia Pasific Journal of Marketing and Logistics, 27(5), p. 735-757.

Fishbein, M., \& Ajzen, I. 2010. Predicting and Changing Behavior: The Reasoned Action Approach. Psychology Press. Taylor \& Francis Group.

Fusva, A., Dean, D., Suhartanto, D., Syarief, M. E., Arifin, A. Z., Suhaeni, T., \& Rafdinal, W. 2020. Loyalty Formation and Its Impact on Financial Performance of Islamic Banks-Evidence from Indonesia. Journal of Islamic Marketing, aheadof-print(ahead-of-print).

https://doi.org/10.1108/JIMA-122019-0258

Jaafar, N. A., Noor, Z. M., \& Mohamed, M. 2016. Student ratings of teaching effectiveness: An ImportancePerformance Analysis (IPA). Journal of Educational and Social Research, 6(3), p. 33-44.

Kabaachi, S., \& Obeid, H. 2016. Determinants of Islamic Banking Adoption in Tunisia: Empirical Analysis. International Journal of Bank Marketing, 34(7), p. 1069-1091.
Kardoyo, Nurkhin, A., Muhsin, Mukhibad, H., \& Aprilia, F. D. 2020. The Effect of Knowledge, Promotion, and Religiosity on Intention to Use Islamic Banking Services. International Journal of Financial Research, 11(2), p. 128-135.

Mansour, W., Hajlaoui, L. L., Abdulkarim, F., \& Nassief, M. 2016. Trust Crisis in Islamic Banking: Empirical Evidence Using Structural Equation Modeling. International Journal of Business, 21(2), p. 157177.

Martilla, A. J., \& James, C. J. 1977. Importance-performance analysis. The Journal of Marketing, 41(1), p. 77-79.

Minta, N. K., \& Stephen, O. 2017. Importance-Performance Matrix Analysis ( IPMA) of Service Quality and Customer Satisfaction in the Ghanaian Banking Industry. International Journal of Academic Research in Business and Social Sciences, 7(7), p. 532-550.

Muslichah, I., \& Sanusi, S. 2019. The Effect of Religiosity and Financial Literacy on Intention to Use Islamic Banking Products. Asian Journal of Islamic Management, 1(2), p. 85-92.

Muslim, Zaidi \& Rodrigue. 2013. Islamic Banks : Contrasting the Drivers of Customers Satisfaction, Image, Trust, and Loyalty of Muslim and Non Muslim Customers in Malaysia. International Journal of Bank Marketing, 31(2), p. 79-97.

Nashori, F., \& Mucharam, R.D. 2002. Mengembangkan Kreativitas dalam Perspektif Psikologi Islam. Menara Kudus. Yogyakarta.

Othman, A., \& Owen, L. 2011. Adopting and Measuring Customer Service Quality (SQ) in Islamic Banks: A Case Study in Kuwait Finance House. 
International Journal of Islamic Financial Services, 3(1).

Otoritas Jasa Keuangan. 2020. Statistik Perbankan Syariah Desember 2020.

Parasuraman, A., Zeithaml, V. A., \& Berry, L. L. 1985. A Conceptual Model of Service Quality and Its Implication for Future Research (SERVQUAL). Journal of Marketing, 49(4), p. 41-50.

Sayani, H. \& Miniaoui, H. 2013. Determinants of Bank Selection in the United Arab Emirates. International Journal of Bank Marketing, 31(3), p. 206-228.

Shieh, I. J., \& Wu, H. 2009. Applying Importance-Performance Analysis To Compare The Changes of A Convenient Store. Quality \& Quantity, 43(1), p. 391-400.

Souiden, N. \& Rani, M. 2015. Consumer Attitudes and Purchase Intentions Toward Islamic Banks: The Influence of Religiosity. International Journal of Bank Marketing, 3(2), p. 143-161.

Suhartanto, D., Farhani, N. H., Muflih, M., \& Setiawan. 2018. Loyalty Intention toward Islamic Bank: The Role of Religiosity, Image, and Trust. International Journal of Economics and Management, 12(1), p. 137-151.

Tailab, M. M. K. 2020. Using ImportancePerformance Matrix Analysis to Evaluate the Financial Performance of American Banks During the Financial Crisis. Sage Open, 10(1), p. 1-17.

Zeithaml, V., Bitner, M. J., \& Gremler, D. 2017. Services Marketing: Integrating Customer Focus Across the Firm. McGraw-Hill Education. 